\title{
Toward global checks and balances
}

\author{
Eyal Benvenisti · George W. Downs
}

Published online: 31 January 2009

(C) Springer Science+Business Media, LLC 2009

\begin{abstract}
The rapid growth and importance of intergovernmental coordination in the regulation of markets, transportation and communication, the environment, and national security poses numerous challenges for democratic accountability within participating states. Direct public participation in the intergovernmental regulatory bodies is generally modest or absent. Information regarding their deliberations is limited. And the multiple oversight mechanisms and supervisory processes that exist at the domestic level of developed democracies that can scrutinize intergovernmental regulatory decisions tend to be lacking. This lack of accountability raises legitimacy concerns, the most prominent of which is the fear executive branch officials will delegate controversial policy decisions to intergovernmental bodies in order to escape democratic deliberation. In this paper we survey the ways that different review venues (other international institutions and national courts) are attempting to cope with these accountability related issues: we argue that national courts may prove to be the most effective venue for promoting democratic accountability. This is not because they are more reliably representative of their domestic constituency or possess a more cosmopolitan perspective than the bodies whose decisions they are reviewing. Rather their relative advantage lies in: (1) the increasing acceptance on the part of domestic courts that inter-judicial coordination is a prerequisite for their continued ability to fulfill their judicial review function; and (2) the visibility that the decisions of these courts possess. Acting together these two forces have the potential to foster greater transparency and public deliberation than most rival venues.
\end{abstract}

\author{
E. Benvenisti $(\bowtie)$ \\ Tel Aviv University, Tel Aviv, Israel \\ e-mail: ebenve@gmail.com \\ G. W. Downs \\ Department of Politics, New York University, New York, NY, USA
}


Keywords International organizations $\cdot$ International law $\cdot$ Informal international law · International tribunals · National courts · Judicial review · Checks and balances $\cdot$ Peer review $\cdot$ Global administrative law

\section{JEL Classification K33}

\section{Background: the new modalities of inter-governmental coordination}

Intergovernmental coordination has become a prerequisite for the regulation of markets, of the environment, of various other aspects of human activity, even of national security. From a democratic perspective, the negative aspects of such transnational coordination are the lesser opportunities it provides for public participation in decision-making and the limited mechanisms it offers to ensure accountability of the coordinating agencies. Of course, public participation in foreign policy matters and in many other areas has often been limited even in advanced democracies. But in recent years the spectrum of issues that has been relegated to decision-making in the transnational sphere has grown dangerously wide. Increasingly inter-governmental coordination offers domestic interest groups and government officials means to circumvent domestic democratic and supervisory processes that had developed over the years through the efforts of civil society, legislatures and courts (Benvenisti 1999). By so doing it threatens to effectively disenfranchise both voters and legislators in a host of areas. ${ }^{1}$ This section describes the two main modalities for intergovernmental coordination, as a prelude to assessing the threats that they pose to democratic accountability (Part II) and of the evolving responses to those threats by inter-governmental institutions and primarily by inter-judicial coordination (Part III).

Inter-governmental institutions (IOs) have long tended to shield a host of government activities from domestic scrutiny for a variety of reasons. The negotiation processes of by which they are established them are largely opaque. The process by which policy is made and the role of different state actors is often is poorly defined and nontransparent, and decisions are often delegated to a bureaucracy over which there is limited oversight. Perhaps most importantly, both legislatures and courts have frequently displayed a continued willingness to accept their subordinate status relative to the executive branch government in conducting what was-and often still isdeemed "foreign affairs" (Benvenisti 1993). International law added another layer of protection: IOs possess an independent legal personality under international law. This provides them immunity from suits in national courts and frees them from being subject to any national rules prohibiting antitrust or protecting creditors against insolvency. As a result, intergovernmental institutions traditionally afforded domestic interest groups an important and less politically visible avenue of influence while affording executive branch officials in member states an equally important way to increase their discretion relative to other branches of government.

\footnotetext{
1 The impact of such coordination on domestic democracy, and also the disadvantages it produces for weaker countries, are analyzed by Weiler (2004); Kingsbury et al. (2005); Benvenisti and Downs (2007).
} 
In recent years the relative autonomy and lack of public accountability of IOs has become more contested. The violent clashes in Seattle in 1999 signaled that NGOs representing or claiming to represent civil society have discovered IOs as the new fora for policy making and started to demand access and participation. NGOs had proved themselves quite influential in exploiting differences among Northern governments and thereby determining the outcomes of international conferences that set up new IOs such as the International Criminal Court and new rules such as the ban on personal landmines. NGOs were knocking on the doors of the Appellate Body of the WTO seeking - and actually receiving- the opportunity to present their views in trade disputes. At the same time, agency problems began to appear. Governments discovered that the bureaucrats and adjudicators they had appointed to insure that their policies were implemented were exploiting the IOs lack of transparency to expand their own authority and to promote their own policies.

These events have led governments to begin to look beyond the traditional IO in order to re-establish and if possible further enhance their autonomy from both international bureaucracies and representatives of civil society. Thus, in addition to the emergence of array of IOs, we see in recent years an even greater effort to develop ad-hoc or flexible, often informal and even private institutions (collectively called here informal transnational institutions, or ITIs). ${ }^{2}$ Governments of some powerful states have even explicitly expressed their preference for ITIs over IOs. Thus, in 2006 the National Security Strategy of the United States describes one of its three priorities in its work with its allies as "Establishing results-oriented partnerships [...]. These partnerships emphasize international cooperation, not international bureaucracy. They rely on voluntary adherence rather than binding treaties. They are oriented towards action and results rather than legislation and rule-making" (U.S. National Security Council 2006, p. 48). ${ }^{3}$ The same document goes on to extol the so-called "coalitions of the willing," suggesting that "[e]xisting international institutions have a role to play, but in many cases coalitions of the willing may be able to respond more quickly and creatively, at least in the short

\footnotetext{
${ }^{2}$ There are at least four types of ITIs: (a) informal government-to-government coordination that characterizes most spheres of activity of contemporary governmental action, including many government agencies such as central bankers, antitrust regulators, securities regulators, criminal enforcement agents, and environmental protection agencies, who harmonize their activities through informal consultations in informal venues, and implement them through their authorities under their domestic laws; (b) non-binding institutions that enable governments sharing common interests to coordinate activities vis-à-vis other states [prevalent in the context of non-proliferation of weapons, such as most recently the Financial Action Task Force (FATF) and the Proliferation Security Initiative (PSI)]; (c) joint ventures between governments and private actors, like in the case of the Global Fund to Fight AIDS, Tuberculosis and Malaria, an entity that is constituted as an independent Swiss foundation; and finally (d) the delegation of authority to set standards to private actors, in areas where governments have been reluctant to act, or have simply preferred to let private actors perform such tasks, ranging from letters of credit and insurance to facilitation of transnational trade, safety standards, accounting standards, and even the setting of core labor rights for developing countries. On these alternatives, see Benvenisti (2007); Slaughter (2004).

3 This new term-partnerships-was absent in the 2002 NSS statement. It connotes something more stable than the previous term "coalitions of the willing" (which appears only once, in reference to the Tsumani aid) but less stable than a formal institution. See, e.g., the description of creation of the International Partnership on Avian and Pandemic Influenza, as "a new global partnership of states committed to effective surveillance and preparedness that will help to detect and respond quickly to any outbreaks of the disease."
} 
term" (U.S. National Security Council 2006, p. 48). A German Directive issued in 2000 in suggests that it too is eager to explore more flexible and informal coordination mechanisms. The Directive requires all German federal ministries to avoid using formal international legal instruments to cement their agreements with foreign parties. The Directive stipulated that negotiators should explore alternatives to formal international undertakings before they commit to such. ${ }^{4}$ Bureaucrats in other relatively strong and affluent nations indicated similar expectations if not formal directives. ${ }^{5}$ Whether this embrace of informality is motivated primarily by a sense of urgency in the face of an unresponsive bureaucracy, or a desire for greater flexibility in dealing with a problem that is rapidly changing, or a calculated effort to minimize transparency and reduce oversight is not clear. However, whatever the motivation for such informality in any particular case it is difficult to escape the fact that it has generally operated to expand the de facto authority of the executive branch in comparison with other branches of government and reduced the opportunities for accountability and deliberation generally. ${ }^{6}$

This is not to suggest that the move from formal IOs to the more flexible ITIs is entirely driven by the desire to escape formal accountability. The search for greater efficiency obviously plays some role and the US national Security Strategy's document evidences a frustration with excessively burdensome processes.

\footnotetext{
4 Article 72 of the Gemeinsame Geschäftsordnung der Bundesministerien [Common Agenda of the Federal Ministries] (2000): (1) "Vor der Ausarbeitung und dem Abschluss völkerrechtlicher übereinkünfte (Staatsverträge, übereinkommen, Regierungsabkommen, Ressortabkommen, Noten- und Briefwechsel) hat das federführende Bundesministerium stets zu prüfen, ob eine völkervertragliche Regelung unabweisbar ist oder ob der verfolgte Zweck auch mit anderen Mitteln erreicht werden kann, insbesondere auch mit Absprachen unterhalb der Schwelle einer völkerrechtlichen übereinkunft." (Collective standing order for all federal ministries of 2000: "Before the planning and the conclusion of international agreements (international treaties, agreements, interministerial or interagency agreements, notes and exchanges of letters) the responsible federal ministry must always inquire whether the conclusion of the international undertaking is indeed required, or whether the same goal may also be attained through other means, especially through understandings which are below the threshold of an international agreement."). http://www.bmi.bund.de/Internet/Content/Common/Anlagen/Broschueren/ 2007/GGO,templateId=raw,property=publicationFile.pdf/GGO.pdf (translated by the authors).

5 "Because the use of MOUs [memoranda of Understandings] is now so wide-spread, some government officials may see the MOU as the more usual form, a treaty being used only when it cannot be avoided. The very word 'treaty' may conjure up the fearsome formalities of diplomacy." (Aust 2000, p. 26). Aust has been a legal adviser at the British Foreign Office.

6 A recent example of this shift relates to the management of shared polar bears populations. In 2000 the US signed a bilateral agreement with Russia on the Conservation and Management of the AlaskaChukotka Polar Bear Population that envisioned the establish a common legal, scientific and administrative framework and the establishing of a "U.S.-Russia Polar Bear Commission," which would function as the bilateral managing authority to make scientific determinations, establish harvest limits and carry out other responsibilities under the terms of the bilateral agreement (Murphy 2003, p. 192-193). In contrast, when in 2008, the US and Canada sought to collectively protect their shared polar bear populations, they chose to do so through their respective administrative agencies. They implemented their joint memorandum of understanding through their respective powers under domestic law. (see Memorandum of Understanding between Environment Canada and the United States Department of the Interior for the Conservation and Management of Shared Polar Bear Populations, May 8, 2008). The MOU states among its aims "to help improve collaboration and the development of partnerships between the Participants and other interested parties" and set up an "ad-hoc Oversight Group" comprising of members of the two agencies and others whom those members would decide to invite. http://www.asil.org/ilib/2008/05/ilib080516.htm\#t1.
} 
Technological developments also play a role. The contemporary ease of communications has led to a significant increase and deepening of coordination among national bureaucracies. Coordination no longer depends on the drafting of formal treaties through emissaries and diplomats. Instead, the relevant decision-makers can negotiate and clarify mutual expectations directly by the simple exchange of phone calls or emails. The speed and availability of communications and a rapidly shifting global economic and political environment has brought diverse parts of national bureaucracies into direct contact, sometimes on a daily basis, with their foreign peers.

But this technology-driven increase in speed and informality comes at a potentially high cost. Its inherent lack of transparency and the ad hoc quality of deliberation make accountability difficult and invite a host of abuses ranging from an illicit centralization of power and unfettered discretion to enabling opportunistic government officials to make politically invisible concessions to powerful private actors. One typical example of private pressure is the functioning of the International Accounting Standards Board (IASB), an ITI that sets global standards for accounting. Mattli and Büthe document the pressures exerted on the IASB chairman by powerful donors to withdraw their financial support "if the IASB failed to show greater sensitivity to their policy preferences" (Mattli and Büthe 2005). In light of the post-Enron decision in the US to make the funding to the American Financial Accounting Standards Board (FASB) involuntary (Mattli and Büthe 2005, p. 249), the voluntary funding of IASB reflects the creative ways through which private interests manage to maintain their pressure on regulatory functions.

\section{IOs, ITIs, and the quest for accountability and participation}

\subsection{Challenges in the supply and demand of monitoring mechanisms of IOs}

Traditionally, IOs such as the WTO and, at least initially, the EU justified their restrictions on public participation by arguing that various constituencies were already represented by their democratically elected governments whose policy positions they retained the ability to influence through their respective domestic processes. This has tended to focus much of the discussion regarding accountability and democratic participation in connection with IO's on the reliability and effectiveness of the voice provided by this indirect vote in supranational fora in which all states are often not represented, where large states are disproportionately influential, and where decisions tend to be reached by means rather other than formal voting. These problems have led to a number of attempts to augment the traditional pattern of indirect representation through other means. There have, for example, been attempts to create the norm that accessible and open channels of communications between the IOs and the public must exist before an IO can claim to be legitimate from a democratic perspective. This was one of the major justifications cited by the German Constitutional Court for its approval of Germany's ratification of the Maastricht Treaty. ${ }^{7}$ The delegation of authority to

\footnotetext{
7 Brunner v. The European Union Treaty, German Federal Constitutional Court Judgment of October 12, 1993 (trans. in [1994] Common Market Law Reports 57).
} 
an integrated European Union, reasoned the Court, can be regarded as consonant with the principle of democracy if that authority provided that, in addition to the retention of "functions and powers of substantial importance" 8 remaining for the national parliaments, it ensured "certain pre-legal conditions, such as a continuous free debate between opposing social forces, interests and ideas, in which political goals also become clarified and change course and out of which comes a public opinion which forms the beginnings of political intentions." 9 To remain true to the ideal of domestic democracy, in the Court's view, "it is essential that the decisionmaking processes of the organs exercising sovereign powers and the various political objectives pursued can be generally perceived and understood, and therefore that the citizen entitled to vote can communicate in his own language with the sovereign authority which he is subject." ${ }^{10}$ Institutionally, the Court emphasizes the role of the European Parliament's "supporting function" and the general requirement to link integration with democratization: "What is decisive is that the democratic bases of the European Union are built-up in step with integration" while at the same time maintaining "thriving democracy" within the member states. ${ }^{11}$

The question that remains is what mechanisms are available at the level of the supranational institution to ensure open channels of communications. The debate about democratic deficit at the EU, and the relatively opacity of the WTO's rather informal prescriptive process suggest that transparency and participation remain challenges to the ideals of accountability and democratic participation. Of course, there are doubtless instances in which NGOs representing diverse interests benefit from this opacity, just as private actors often benefit from informal processes and social networks in connection with their lobbying in any state (Dunoff 1998). ${ }^{12}$ But this influence remains a matter of discretion for states rather than a right and hence potentially arbitrary. As a result states may find it opportune to support NGOs representing labor unions in developed countries but not NGOs committed to promoting other interests such as an end to agricultural subsidies or a restricting arms sales. Widening the avenues for participation remains an uphill battle waged by several NGOs.

Perhaps the most persistently troubling aspects of multilateral IOs with representation and accountability relate to the lack of effective voice for the developing world. Developing states are less well represented in most IO's than are developed states, and tend to enjoy far less positional power than the major developed states that created the rules by which they operate. ${ }^{13}$ Serious questions have also been raised about the extent to which some developing democracies are adequately representing their populations. For example, several Southern governments have long resisted transparency in WTO processes so as to preempt NGO

\footnotetext{
${ }^{8}$ Id., at page 88 (Section $\left.\mathrm{C}(\mathrm{b})(2)\right)$.

9 Id., at page 87 (Section $\mathrm{C}(\mathrm{b})(1))$.

${ }^{10}$ Id. id.

11 Id., at page 87 (Section C(b) (2)).

12 For an appraisal of the debate see Stein (2001, p. 504-509).

13 For a discussion of the impact of governance through IO on developing countries and their responses see Benvenisti and Downs (2007, p. 619-625).
} 
pressure to improve labor standards. In contrast, the UNDP and the World Bank have become aware of this matter and have begun to address this challenge. ${ }^{14}$

\subsection{Challenges in the supply and demand of monitoring mechanisms of ITIs}

In comparison with IOs generally, relatively little attention has been focused on the accountability problems connected with ITIs. Much of this is probably attributable to their relative newness and lack of political visibility, but there are also those who are skeptical that such problems are really important enough to warrant attention. One group stresses the fact that informal coordination among officials does not constitute formal delegation of authority. National administrative agencies continue to retain formal decisional authority and citizens continue to possess the same tools they have always used to monitor governmental agencies and to participate in their decision-making processes remain as relevant and as effective as ever. Others argue that the professionalism and impartiality of the non-governmental decisionmakers who are involved in ITIs makes more formal accountability mechanisms unnecessary (Freeman 2000, p. 666). ${ }^{15}$ Here the reasoning appears to emphasize the expertise of the decision-maker. The underlying assumptions appear to suggest that by insuring impartiality one also ensures the requisite accountability (as if there was a reliable connection between expertise and incorruptibility or that expertise was a reliable predictor of political innocence, or that risk-management by experts is devoid of politics). ${ }^{16}$

This may be true, at least to some extent, for some informal institutions that can be found in the domestic sphere (Freeman 2000; describes those institutions). In the domestic setting, the traditional tools to ensure accountability and participation can be backed up by recourse to the legislature or to the court to restrain runaway agencies. But the same is not necessarily true for ITIs. The motivations of interest groups and the executive to resort to formal coordination through IOs that were mentioned above resonate also in the context of the move to set up ITIs: by moving to inter-governmental bargaining, and also to bargaining between governments and different private actors, the issues and the impact of outcomes become more opaque to civil society. In such circumstances of relatively little information, the opportunity to capture officials by interest groups and, the impact of pressure by foreign governments, are at their height. At the same time, because the legislature

\footnotetext{
14 The World Bank in particular has been quite successful in strengthening the capacities of southern NGOs: see World Bank, "The World Bank and NGOs in China" (available in http://web.worldbank. org/WBSITE/EXTERNAL/COUNTRIES/EASTASIAPACIFICEXT/CHINAEXTN/0,,contentMDK: $20600360 \sim$ pagePK:141137 piPK:141127 theSitePK:318950,00.html\#Assisting_the_government_ in_providing_an_enabling_environment_for_NGO_development_in_China). For a general discussion of this issue see Edwards et al. (1999).

15 "Public/private arrangements can be more accountable because of the presence of powerful independent professionals within private organizations. The background threat of regulation by an agency can provide the necessary motivation for effective and credible self-regulation. The two principal partners in a regulatory enterprise (the agency and the regulated firm, or the agency and the private contractor) might rely on independent third parties to set standards, monitor compliance, and supplement enforcement."(Freeman 2000, p. 666).

${ }^{16}$ For criticism see Kennedy (2005).
} 
and the domestic court have traditionally found themselves institutionally less capable of intervening in the way their government conducts its foreign ties with other governments and international institutions, these institutional checks on governmental action may not offer a comparable monitoring service as they have offered with regard to domestic decision-making processes. Hence the demand for institutional restraints on the government acting through ITIs should be at its height to guarantee adequate accountability while the supply side is wanting.

\section{Toward a realignment of global checks and balances? Assertion and reassertion of authority to review inter-governmental action}

This part surveys emerging mechanisms for reasserting review authority over IO and ITI decision-making procedures and over their decisions. Although these review mechanisms are not themselves democratically representative, we suggest that their intervention in the decision-making process often increases accountability and promotes public deliberation which, in turn, contribute to the adoption of public policies that take account of the interests of wider constituencies. There is even some scattered evidence to suggest such review mechanisms sometimes manage to level the global playing field between strong and weak, North and South. Section 3.1 mentions the possibility of internal IO review, Sect. 3.2 discusses the possible evolution of inter-IO review. Section 3.3 describes the possible role of national courts.

\subsection{Internal IO review}

A few IOs have possess their own internal review mechanisms and procedures. The EU is a clear example here, with its elaborate system of judicial review (Klabbers 2002, p. 237). ${ }^{17}$ In most other IOs, such procedures are less explicit and their evolution depends on the relative willingness of the governments involved to tolerate such review. As Jan Klabbers notes, while other IOs besides the EU have "some rules" relating to the validity of their decisions, "their rules are so broadly circumscribed as to be incapable of any practical application" (Klabbers 2002, p. 245). The degree of consensus among states is important in this regard: when an overwhelming majority of the state parties to an IO accept a certain decision of the IO, review of the decision's legal validity is relatively rare (Klabbers 2002, p. 237).

This is also the case of the United Nations. The International Court of Justice, the "principal judicial organ" 18 of the UN, refused to review decisions of the other organs of the UN, referring to the fact that "Proposals made during the drafting of the Charter to place the ultimate authority to interpret the Charter in the International Court of Justice were not accepted." 19 "Undoubtedly," It asserted,

\footnotetext{
17 On EU internal review procedures that create "a democratizing destabilization effect" see Cohen and Sabel (2005, p. 782-784).

18 Article 92 UN Charter.

${ }^{19}$ Certain expenses of the United Nations advisory opinion 1962 at p. 168.
} 
"the Court does not possess powers of judicial review or appeal in respect of decisions taken by the United Nations organs concerned." ${ }^{20}$ Despite much scholarly criticism, ${ }^{21}$ the ICJ did not accept the invitation to second-guess the legality of the Security Council's Resolution to impose sanctions on Libya. ${ }^{22}$ It did accept the request of the General Assembly to give an advisory opinion on the "Legal Consequences of the Construction of a Wall in the Occupied Palestinian Territory," 23 despite the fact that the Security Council had made an earlier resolution on "the situation in the Middle East, including the Palestinian question," and had decided to "remain seized of this matter" (Security Council Resolution 1515 2003). ${ }^{24}$ But it went out of its way to emphasize the extraordinary circumstances of the singular situation, so that it would not be viewed as a challenge to the Security Council's authority and set a precedent for future intervention. $^{25}$

The ICJ recognizes a strong presumption in favor of the legality of acts of other UN Organs as well as of other IOs. Its approach is summarized by Jan Klabbers as follows: "as long as an act of an organization ${ }^{26}$ can somehow be fitted into the scheme of that organization's purposes, there is at least a presumption that the organization was entitled to undertake that activity" (Klabbers 2002, p. 237). In addition, the ICJ adopted a permissive attitude toward the accretion of powers by other organs of the UN. It found implicit authority in the UN Charter for the General Assembly's establishment of the UN Administrative Tribunal, ${ }^{27}$ thereby providing strong backing to the evolution of the general doctrine of "implied powers" according to which IOs have powers beyond those enumerated in the original treaty provided they can be linked to the purposes of the IO (Alvarez 2005, p. 92-95; Klabbers 2002, p. 270-271).

\footnotetext{
${ }^{20}$ Legal Consequences for States of the Continued Presence of South Africa in Namibia (South-West Africa) Notwithstanding Security Council Resolution 276 (1970), 1971 I.C.J. Reports 16, at para. 89 (Advisory Opinion of 21 June 1970).

21 A sample of this rich debate includes: Franck (1992), Reisman (1993), McWhinney (1992), Watson (1993), Gowlland-Debbas (1994) and Alvarez (1996). See De Wet (2004).

22 Case Concerning Questions of Interpretation And Application of The 1971 Montreal Convention Arising from the Aerial Incident at Lockerbie (Libyan Arab Jamahiriya V. United States of America), Request For The Indication Of Provisional Measures, 14 April 1992.

23 The General Assembly's Resolution is Resolution ES-10/16 (3 December 2003). For the Advisory Opinion see Legal Consequences of the Construction of a Wall in the Occupied Palestinian Territory, ICJ Advisory Opinion, ICJ Reports 2004, 136 (9 July 2004).

24 Security Council Resolution 1515 (19 November 2003).

25 Legal Consequences, supra note 23, at paras. 49-50 ("The responsibility of the United Nations in this matter also has its origin in the Mandate and the Partition Resolution concerning Palestine (...). This responsibility has been described by the General Assembly as 'a permanent responsibility towards the question of Palestine until the question is resolved in all its aspects in a satisfactory manner in accordance with international legitimacy' [...] The object of the request before the Court is to obtain from the Court an opinion which the General Assembly deems of assistance to it for the proper exercise of its functions. The opinion is requested on a question which is of particularly acute concern to the United Nations.").

26 Klabbers refers not only to the UN as an IO, but to any IO (Klabbers 2002, p. 237).

27 Effect of Awards of Compensation Made by the United Nations Administrative Tribunal (1953-1954) 1954 I.C.J. Reports 47 (Advisory Opinion of 13 July 1954).
} 
In general, it is difficult to escape the conclusion that the evolution of review possibilities within IOs will be shaped by the balance of power between governments within each of the institutions and the degree of consensus that exists among them on a given issue (Benvenisti 2005, p. 319). To the extent that a given coalition of states is dominant or there is broad consensus among states, the potential for the emergence of robust review possibilities is not very significant.

\subsection{IOs reviewing each other}

Inter-IO review-sometimes referred to as "peer review" (Grant and Keohane 2005; Cohen and Sable 2005 , p. 790-794) ${ }^{28}$-constitutes a potentially effective form for inter-institutional review. There are several international bureaucratic or judicial bodies that have ample opportunities to monitor and even pass judgment over decisions of other institutions. The European Court of Justice, the European Court on Human Rights, The International Court of Justice, The Appellate Body of the WTO are some of the key candidates for exercising indirect judicial review of each other. Such indirect review could include a review of the compatibility of the IO's act with its constituting treaty, an examination of the legality of the act under governing norms of international law, or the conformity of that act with the legal system of the reviewing IO.

To date, however, the potential for formal peer review among IOs remains largely unrealized. The general tendency of bureaucrats and judges in IOs is to tacitly coordinate with their colleagues in other international institutions (as well as with weaker state parties) (Benvenisti and Downs 2007, p. 623-624). They do this by recognizing each others' precedents and by adopting each other's legal doctrines. In the case of judges, the goal is to create consistent jurisprudence of international law, because the more consistent the law is, the more authority it generates. This inter-tribunal coordination enhances the role of all the tribunals since the united position they adopt is seen as convergence on undisputed principles. International tribunals show deference to each other, and strive to conform with previous rulings of their peers. This is especially the case when the International Court of Justice has ruled. The latter enjoys the standing as the highest judicial body, despite the fact that no such hierarchy is explicitly stipulated.

This coordination strengthens the coherence and consistency of legal argument across institutions which directly reduces their own transaction costs. To the extent this trend succeeds in reducing the variance in how a given legal claim will be viewed by different institutions it should also gradually reduce the benefit that powerful states obtain by shifting between existing venues or seeking to manipulate the composition of the decision-makers.

International law provides relatively independent bureaucracies and judiciaries with three doctrines by which they can expand their authority while maintaining coherence and consistency: the expansive interpretation of treaties, the doctrine of implied powers of IOs, and the doctrine on customary international law (CIL). This

\footnotetext{
28 "Peer accountability arises as the result of mutual evaluation of organizations by their counterparts" (Grant and Keohane 2005).
} 
possibility enlarges the discretion on the part of both of these actors and thereby increases their ability to flee from domestic accountability. In recent years they have frequently if not always successfully employed these tools often in the face of considerable opposition by the reigning coalition of powerful developed states. This is reflected in the conflicting approaches to the question of treaty interpretation. The law on treaty interpretation as prescribed in the Vienna Convention on the Law of Treaties (1969) can be read as privileging an interpretation that looks back to the historical intention of the negotiators, or to subsequent governmental practice, thereby maximizing governments' influence on the outcomes of the interpretation process. ${ }^{29}$ However, international tribunals have developed alternative interpretative approaches to ensure that the treaty effectively achieves its goals, reading into it additional obligations if necessary. ${ }^{30}$ In addition, international tribunals depart from the historical bargain by adapting it, through the techniques of "evolutionary" (Bernhardt 1999) or "systemic" (Maclachlan 2005; French 2006) that adapt the treaty provisions to contemporary standards. ${ }^{31}$ This general doctrine of expansive treaty interpretation serves as the basis for the second doctrine that focuses specifically on IOs. International tribunals have interpreted treaties that established IOs in ways that enhanced the IOs (as well as their own) powers. Internally, international courts tended to strengthen the institution's authority and impact vis-àvis state parties beyond what the negotiators have intended. The doctrine of "implied powers" indicates that IOs must be deemed to have sufficient powerseven if not enumerated in the founding text— to accomplish their mandate. ${ }^{32}$ The same concern has led the same courts to recognize the IOs status as "subjects" of

\footnotetext{
29 The Vienna Convention, Article 31 (that seeks to explore "the ordinary meaning" of the treaty in light of its text and its context, the context being primarily subsequent treaties and practice) and especially Article 32 (which adds supplementary means of interpretation that include the preparatory work of the treaty and the circumstances of its conclusion, in order to confirm the meaning when the interpretation according to Article 31 leaves the meaning ambiguous or obscure or leads to a manifestly absurd or unreasonable result).

30 Such an outlook enables the courts to explore what Lauterpacht calls "the principle of effectiveness" in treaty interpretation: "The activity of the International Court has shown that alongside the fundamental principle of interpretation, that is to say, that effect is to be given to the intention of the parties, beneficient use can be made of another hardly less important principle, namely that the treaty must remain effective rather than ineffective... The principle of effectiveness of obligations, conceived as a vehicle of interpretation, is an instrument of considerable potency. It may be as comprehensive as all the rules of interpretation taken together" (Lauterpacht 1958, p. 227-228, 267-283).

31 For example, in its Shrimp/Turtle decision, for example, the WTO AB invoked the "contemporary concerns of the community of nations about the protection and conservation of the environment" as a basis for the interpretation of GATT, explicitly playing down the significance of the preparatory work of the treaty, because of "the secondary rank attributed to this criterion by the Vienna Convention, the lack of reliable records, and the ambiguities resulting from the presence of contradictory statements of the negotiating parties." [United States-Import Prohibition of Certain Shrimp and Shrimp Products, WTO Doc. WT/DS58/AB/R, reprinted in 38 ILM 118 (1999)]. Note however, that governments invest in keeping the record of such negotiations. As Steinberg found in the WTO context, "in many instances minutes of formal meetings in which negotiations took place are available, as are draft and bracketed texts, domestic legislative reports and testimony that indicate a state's understanding of a provision, and good secondary histories and commentaries (Steinberg 2004, p. 247, 251, 261).

32 Klabbers suggests (2002, p. 78-80) that the expansive "implied powers" doctrine has come "under fire" in the 1990s (at least with respect to the EC). In other words, the member states have started to reclaim control over accretion of authority. See also Alvarez (2005, 92-95).
} 
international law. Like corporations in domestic law, IOs have an distinct legal personality. Therefore they can conclude treaties with third parties and are not affected by obligations incurred by the member states.

The third doctrine that has enabled international decision-makers to increase their discretion and hence their authority is the doctrine of CIL. ${ }^{33}$ International tribunals exercise considerable discretion in both "finding" state practice and in determining whether such practice betrays states' acknowledgement of its binding quality, which would then constitute CIL norm. Courts rarely engage in systematic review of state practice and instead use proxies such as adopted treaties or decisions of other international institutions as reflecting state practice. ${ }^{34}$ The norms of CIL are then referred to as binding on the IOs and therefore authorizing, even requiring, the IOs to take those norms into account.

This concerted effort to create a coherent and consistent legal space is usually not openly acknowledged. These doctrines are asserted as self-evident. Being part of the mutual effort restricts the possibilities of mutual criticism. Tribunals are bound to keep the rules of the legal space which sustains their own authority. Any criticism of their peers could expose their own weaknesses. As a consequence, these tribunals rarely challenge each other's interpretation of the same legal text, and invariably refrain from criticizing the use of these three abovementioned approaches.

It is telling that while tribunals have shown a readiness to impose unenumerated duties on state parties - thereby increasing the IOs' authority to review the state party's policy - they have refrained from imposing such duties on peer IOs. The Appellate Body of the WTO could link trade norms with environmental norms, imposing added constraints on trading state parties. But it could not impose such norms on other IOs, like, for example, the EU. The formal legal reason that is provided is based on the entrenched doctrine-derived from the distinct legal personality of the IO-that IOs are not bound by norms they have not explicitly adhered to. The United Nations, for example, is not legally bound to respect human rights norms because it is not a party to human rights treaties. The contrast between these two legal outcomes is another clear reflection of the readiness of IOs to impose additional constraints on state parties but not on peers.

An example that demonstrates the promise and the limits of inter-IO review is the recent litigation concerning the "smart sanctions" regime imposed by the Security Council on individuals involved in the financing of global terrorism. Both the ECHR and the ECJ were seized with petitions against the EU's and the member states of the ECHR's compliance with those sanctions that included the freezing of bank accounts of individuals without a prior (or subsequent) hearing. The interim judicial outcometwo decisions of the ECJ's Court of First Instance (CFI) in $2005^{35}$ —signaled that

\footnotetext{
33 As Lauterpacht observed already in 1958, "In few matters do judicial discretion and freedom of judicial appreciation manifest themselves more conspicuously than in determining the existence of customary international law"(Lauterpacht 1958, p. 368).

34 As Theodor Meron observed recently, "[n]otably absent from many of these cases [in which international tribunals invoked CIL] is a detailed discussion of the evidence that has traditionally supported the establishment of the relevant rules as law" (Meron 2005, p. 817, 819).

35 CFI, 21 September 2005, Case T-306 and Case T-315 Yusuf and Al Barakaat, and Kadi v. Council of the European Union and Commission of the European Communities.
} 
court's willingness to review Security Council Resolutions only under the elusive concept of jus cogens. ${ }^{36}$ But Jus cogens norms refer to abhorrent practices such as slavery and torture, practices that cannot be contracted out by states, whereas due process, or good governance norms hardly amount to such gross violations of basic principles. The limited scope of review offered by the CFI resulted from the selfperception of the CFI as belonging to the same legal order to which the UN belonged. On appeal to the Grand Chamber of the ECJ, the court's Advocate General suggested a radical departure from that vision of a hierarchy within a unitary legal structure. Ultimately accepted by the court, ${ }^{37}$ the opinion depicts the European legal order as distinct from the international one. Both Advocate General Maduro and the Grand Chamber envision the European legal order as essentially a non-international order, one that is not based on a ubiquitous inter-state treaty but rather, as described by Maduro, on "an agreement between the peoples of Europe." 38 As a consequence, the international pyramid of norms is turned on its head: it is not the UN Charter which dominates EU law based on the primacy of Article 103 of the UN Charter, ${ }^{39}$ but rather the EU law that enjoys legal supremacy ${ }^{40}$ The Grand Chamber adopted this view, basing its authority to review the implementation of the Security Council's Resolutions on "the internal and autonomous legal order of the Community." 41 This "legal exit" from the sphere of international law is an exercise in "judicial fragmentation" which runs contrary to the general effort to create coherence and consistency.

The treatment of IOs under international law as independent legal entities is another factor that inhibits the evolution of inter-IO review. Domestic review of the executive has developed in many democracies based on the premise that in a democracy the executive was an agent who should be closely monitored to ensure its compliance with the wishes of the principal. For example, domestic administrative law in England and in the Continent evolved by administrative courts based on the theory that the administrative agencies should have no more powers than

\footnotetext{
36 According to the Vienna Convention on the Law of Treaties, a treaty is void "if, at the time of its conclusion, it conflicts with a peremptory norm of general international law. For the purposes of the present Convention, a peremptory norm of general international law is a norm accepted and recognized by the international community of States as a whole as a norm from which no derogation is permitted." (Art. 53).

37 Kadi, opinion of 16 January 2008.

38 Id., para 21, emphasis in original. The Rome Treaty had established a 'new legal order', beholden to, but distinct from the existing legal order of public international law. In other words, the Treaty has created a municipal legal order of trans-national dimensions, of which it forms the 'basic constitutional charter'.

39 Art. 103 states: "In the event of a conflict between the obligations of the Members of the United Nations under the present Charter and their obligations under any other international agreement, their obligations under the present Charter shall prevail".

40 "In the final analysis, the Community Courts determine the effect of international obligations within the Community legal order by reference to conditions set by Community law." Supra note 37, at para. 23 Therefore, "The relationship between international law and the Community legal order is governed by the Community legal order itself, and international law can permeate that legal order only under the conditions set by the constitutional principles of the Community." Id., para 24.

${ }^{41}$ Grand Chamber decision in Kadi v. Council of the European Union and Commission of the European Communities (ECJ, September 3, 2008).
} 
those granted to them by the democratically elected legislature. As subject to legislative authority, the domestic administrative agencies were subjected to the doctrine of ultra vires, and their powers were interpreted narrowly to ensure that they adhered to appropriate democratic constraints. In contrast, in the international legal arena IOs are not treated as agents of state-parties, but rather as having a distinct legal status, as principals. They are the equivalent in international law to corporations in domestic law. Hence, the only theory that can sustain the evolution of IO review will be the equivalent in international law to the domestic theory of contract which is not informed by an underlying concern for democracy. The doctrine of implied powers of IOs can only be understood as flowing from such a vision of institutional independence.

Inter-IO review presents not only risks to the self-interest of the individual IO, but also arguably threatens the vision of creating an effective global legal order of which the different IOs form parts. Intra-state review is capable of sustaining internal review processes, without threatening the integrity of the domestic legal order. This is the case because the domestic legal system is based on a formal hierarchy of norms and institutions and therefore disputes between domestic institutions will ultimately be resolved according to those hierarchies. In contrast, the international legal scene is fragmented and there is no consensus on either normative or institutional hierarchy. It lacks the domestic tools that regulate conflicts between different institutions and prevent spirals of retaliations between reviewing and reviewed institutions. This raises the prospect that if a process of retaliation should result from one IO criticizing another for narrowly interpreting a treaty or by refusing to find state practice as reflecting CIL, that peer (and others) would retaliate in kind resulting in an even more fragmented and far weaker system of international law than that which currently exits. As a consequence, members of IOs, who are typically those who are inclined to promote global cooperation through that vision, have hesitated to engage in systematic peer review.

\subsection{The emergence of domestic checks on IOs and ITIs}

Direct review of IOs by national courts is rarely available. In fact, the prevailing doctrine in international law provides immunity for IOs from domestic adjudication, as if they were foreign sovereigns (Reinisch 2007). ${ }^{42}$ Nevertheless, domestic courts have a range of options to rationalize their negative reaction to actions of IOs and ITIs. Their reaction can be a refusal to give effect to an act of the IO, following a finding that the act was outside the scope of authority of the IO (such as the Danish court's assertion in 1998 of its power to question the legality of an EC act), ${ }^{43}$ or incompatible with another set of norms, be it international norms (such as a jus cogens norm or a human rights norm ${ }^{44}$ ) or a norm of the domestic legal order that

\footnotetext{
${ }^{42}$ Discussing inter-judicial dialogue in the areas of state immunity and the immunities of international organizations.

43 Carlsen v. Rasmussen, (judgment 6 April 1998), [1999] CMLR 855 170, 174 (The court finds that the Danish courts can declare such acts inapplicable in Denmark).

44 Swiss Supreme Court in the case of Nada v. SECO (decision from November 14, 2007, not yet reported officially, available at http://jcb.blogs.com/jcb_blog/files/tf_youssef_nada.pdf (regarding the
} 
has precedence over the act of the IO (such as the practice of the German constitutional court in the cases involving judgments of The $\mathrm{ECJ}^{45}$ and the $\mathrm{EctHR}^{46}$ ). A domestic court can also indirectly review IO acts without affecting them, such as in the case of a soldier refusing to participate in an "act of aggression" perpetrated by a Security Council Resolution (Schultz 2006). In the case of ITIs, the room for domestic review is theoretically larger given the fact that the decision of the ITI is effected through a formally domestic act.

As noted earlier, national courts have traditionally refrained from reviewing their own governments' dealings with foreign governments. However, more recently these courts have exhibited a willingness depart from this traditional deference and in some key areas they have begun to adopt a more assertive position vis-à-vis their governments. While their rationale for this new tendency toward assertiveness doubtless varies, it seems likely that as acute political actors these courts have come to realize that, under conditions of increased inter-governmental interaction through either more formal IOs or the more flexible ITIs, continuing to allow the executive branch unconstrained authority in international affairs risks impoverishing the domestic democratic and judicial processes and reducing the opportunity of most citizens to use these processes to shape outcomes. By aggressively restricting their governments they stand to enhance this eroded accountability and to secure their own autonomy in the process. The latter concern is particularly important. The expansion of judicial authority in the last two decades ${ }^{47}$ is an achievement the judges are not readily yielding.

Domestic courts need to protect the domestic democratic space and their newly acquired role in society from two types of challenges. One is the coordinated action of governments, who are moving to regulation in the international sphere, through IOs (like the UN Sanctions Committee) or ITIs (FATF anti laundering guidelines). The other is the impact of decisions of judicial bodies of IOs, such as the ICJ, the ECJ or the WTO Appellate Body.

Since 2000 there appears to have been a growing assertiveness of domestic courts vis-à-vis intergovernmental action that seeks to limit judicial review powers and thereby to limit individual rights. This is present in two areas in particular: the judicial review of global counterterrorism measures and the determination of status and rights of asylum seekers in destination countries. So far these courts intervened by rejecting policies adopted by their own governments or legislatures, rather than

\footnotetext{
Footnote 44 continued

UNSC's so-called smart sanctions). The possibility of judicial review by national courts of Security Council Chapter VII Resolutions is discussed by De Wet and Nollkaemper (2002).

45 Known as the "solange" ("as long as") line of cases: In a series of judgments, the German Federal Constitutional Court said that it would comply with decisions and judgments of European institutions "as long as" these decisions are compatible with the values of the German Basic Law (Kokkot 1998).

46 In 2005 The German Federal Constitutional Law asserted that national courts do not have to enforce EctHR decisions without reflection, since they have to implement international law with care (Richter 2006).

47 For more information on the expansion of judicial power (and judicial autonomy) in recent years see Hirschl (2004) (explaining this phenomenon as resulting from elites' attempt to secure their dominant positions against challenges of the majority through the political process) and Stone (2007, p. 69, 80-81).
} 
acts of IOs and ITIs. But these intervening courts invoke a claim that has a clear bite also in that context: several domestic courts increasingly assert their own role as guardians of the domestic legal system, the keepers of the integrity of the domestic rule of law and the constitution. ${ }^{48}$ This can be viewed as a recasting of the ancient assertion of sovereignty on the part of national courts in an effort to provide a theoretical legal basis for establishing their authority in the spheres of foreign affairs and national security, which until very recently were deemed immune to judicial intervention.

Thus, in its judgment concerning the constitutionality of Germany's accession to the Maastricht Treaty, the German Constitutional Court asserted its authority, under German law, to review the actions of the European institutions:
"[I]f European institutions or agencies were to treat or to develop the Union Treaty in a way that was no longer covered by the Treaty in the form that is the basis for the [German parliament's] Act of Accession, the resultant legislative instruments would not be legally binding within the sphere of German sovereignty. The German state organs would be prevented for constitutional reasons from applying them in Germany. Accordingly the [German] Federal constitutional Court will review legal instruments of European institutions and agencies to see whether they remain within the limits of the sovereign rights conferred on them or transgress them." 49

It seems likely that national courts seeking to protect the integrity of their domestic legal system and their autonomous space will increasingly engage themselves in reviewing the actions of IOs and ITIs. Because domestic courts are more concerned with the integrity of their own legal system, but are less (or even not at all) dependent on the integrity of the international legal system, they are likely to have little hesitation to exercise searching review of IO decisions. As a result, we believe that in the future it is likely that domestic courts will be scrutinizing IOs and ITIs far more closely than their peer institutions at the international level.

A decision that demonstrates the stronger domestic determination to review IO action is the House of Lords' judgment in Jedda v. Saudi Arabia of 12 December

\footnotetext{
48 A (FC) and Others (FC) v. Sec'y of State, 2004 U.K.H.L. 56 (2004) (the so-called Belmarsh detainees case) (Lord Bingham, para. 42); in the Queen's Bench decision that forced the continued criminal investigation of possible bribes given to Saudi officials by a British company, investigation that was deemed to seriously harm national security interests, Justice Moses invoked "the need for the courts to safeguard the integrity of the judicial process" and the "responsibility to secure the rule of law." (The Queen on the Application of Corner House Research and Campaign Against Arms Trade and The Director of the Serious Fraud Office and BAE Systems PLC [2008] EWHC 714 (Admin) (2008). Paras. 91 and 171, respectively). In April 2008, The Nagoya High Court in Japan declared that the Japanese operations in Iraq were unconstitutional: Craig Martin, Rule of law comes under fire, The Japan Times 3 May 2008 (http://search.japantimes.co.jp/cgi-bin/eo20080503a1.html). In May 2008 the German Federal Constitutional Law has found the participation of German air force personnel in NATO-led activities to have violated the domestic obligation to seek parliamentary approval (BVerfG, 2 BvE 1/03 vom 7.5.2008, Absatz-Nr. (1-92), http://www.bverfg.de/entscheidungen/es20080507_2bve000103.html).

49 Supra note 7 at page 89 (part C(c)). For similar positions of the Polish and also the Spanish courts see Adam Lazowski, Case Note: Polish Constitutional Tribunal-Conformity of the Accession Treaty with the Polish Constitution, Decision of 11 May 20053 European Constitutional Law Review 148 (2007).
} 
$2007 .^{50}$ At issue was the source of legal authority of the British forces in occupied Basra. of a person held by British troops in Iraq. If Britain operated under the instructions of the UN Security Council, it was not required to follow the strict requirements of the ECHR concerning the detention of Iraqis (because the SC Resolution, being a Chapter VII Resolution, overrides any other treaty obligations). The House could have accepted the government's claim, a claim that had been endorsed by the EctHR in a different context. ${ }^{51}$ But four of the five Lords found that the UN Resolution only qualified and did not displace the ECHR obligation, to the extent that British forces, although acting under UN mandate and as such not obliged to comply with the ECHR in its entirety, still were required not to deviate from the ECHR unless such deviation was "necessary for imperative reasons of security." Thus, although the House does not assert a direct authority to review UNSC Resolution, it does recognize its authority to impose restrictions on Britain's compliance with such Resolutions. ${ }^{52}$

As noted previously, the theoretical explanation of this new phenomenon should focus on the motivations of the national courts and on the logic of inter-judicial coordination. A national court that reviews policies that had been collectively adopted by governments enhances not only the accountability of the executive but also its own authority to interpret and apply national law and the law of the IOs of which its state is party to. The move to IOs, as much as it meant less discretion to national administrative agencies, also meant a growing challenge to the national courts. While traditional deference to the executive branch initially delayed their response, national courts have awoken to the challenge. In the process they have discovered that in contrast to their legislative branches and to IOs themselves they are almost as well-positioned to exploit the fragmentation of IOs to their benefit as is the executive branch. Their main tool in this context is their self-asserted role as the guardians of the domestic legal system, and their ability to control the channels through which international law, including IO decisions being part of that law, are legally binding domestically. This gives national courts to the ability to effectively "de-fragment" conflicting international legal standards as they will be applied within their domestic jurisdictions. For example, a national court might choose to link human rights obligations to the legal regime of refugees or suspected terrorists, thus managing to add layers of protection not provided by the immediately relevant treaty regime. Given the ability (discussed infra) of courts to create a coherent and consistent legal space, it can be expected that they eventually create a web of linked obligations out of the fragmented treaties that is integrated to an extent that is rarely if ever approached at the international level.

Probably the most effective way for national courts to respond to the challenge presented by international tribunals is to preempt them by aggressively participating in the process of lawmaking themselves. As a purely doctrinal matter, national

\footnotetext{
${ }^{50}$ R. (on the application of Al-Jedda) (FC) (Appellant) v Secretary of State for Defence (Respondent) [2007] UKHL 58).

51 Behrami and Behrami v. France and Saramati v France, Germany and Norway (2007) 45 EHRR SE10 (action under UNSC in Kosovo was attributed to the UN rather than to the participating states).

52 Al-Jedda, supra note 50.
} 
courts are directly and indirectly engaged in the evolution of customary international law: their decisions that are based on international law are viewed as reflecting customary international law, ${ }^{53}$ and their government's acts in compliance with their decisions will constitute state practice coupled with opinio juris. As such, international tribunals will have to pay heed to national courts' jurisprudence. It follows that the more the national courts engage in applying international law and the more united they are with respect to the arguments they employ, the more their jurisprudence will constrain the choices available to the international courts when the latter deal with similar issues. Collective action among national courts is critical. While a national court acting alone is unlikely to meaningfully shape the evolution of customary international law, the judgments of several national courts will be difficult for international tribunals to ignore, especially since the tribunals are well aware that national courts will often play a central role in implementing the tribunals' judgments. ${ }^{54}$ National courts that engage in a serious application of international law send a strong signal to international courts, that the national courts regard themselves equal participants in the transnational law-making process and will not accept just any decision rendered by an international tribunal. Since the effectiveness of international tribunals depends on compliance with their decisions, they must anticipate the reaction of the national courts to those decisions and come to terms with their jurisprudence. In this sense, assertive national courts invoking international law can effectively limit the autonomy of the international tribunals, or at least initiate an informal bargaining process in which they are relatively equal partners.

In order for national courts to be collectively effective in the long run, they must coordinate their actions and create a common judicial front (Benvenisti 2008a, b) ${ }^{55}$ Any given court knows that if it alone makes series of rulings that are perceived to be direct challenge to a major international agreement or tribunal, it would face the danger of being marginalized as troublemaker, whose jurisprudence does not reflect general state practice. Should this be the case, the country's reputation as a responsive partner in the globalization process would suffer. Foreign decisionmakers, including powerful foreign governments, international institutions, and even private companies would become more reluctant to deal with it the future, and it could suffer both a loss of prestige and a divestment of foreign capital. If, however, a significant number of state courts were to act collectively, the costs to other states of imposing a collective punishment on all of them would likely be too

\footnotetext{
53 See, for example, the International Court of Justice judgment in Arrest Warrant of 11 April 2000 (Congo v. Belg.), 2002 I.C.J. 3 (Feb. 14), available at http://www.icj-cij.org/icjwww/idocket/ iCOBE/iCOBEframe.htm (last visited Apr. 4, 2007) (examining national courts' jurisprudence to assess the extent to which heads of state enjoy immunity in foreign courts).

54 McNollgast discusses the interplay between a supreme court (as the principal) and lower courts (as its agents) (McNollgast 2006; McNollgast 1995). The dependence of an international tribunal on national courts that are not formally bound by its decisions is even greater. The tense relations that developed between the European Court of Justice and some of the national courts, in particular the German and the Italian courts confirm this theoretical observation (Kokkot 1998; De Witte 1999, p. 177-213).

55 Analysing inter-judicial cooperation in the areas of counterterrorism measures, refugee status and environmental protection (Benvenisti 2008a); discussing inter-judicial cooperation in the area of counterterrorism (Benvenisti 2008b).
} 
high to be practical. The same logic also works in the domestic sphere: a court that unilaterally challenges an international agreement could be subjected to pressures by the executive or public opinion in its own country for its peculiar and potentially harmful judgments. Courts can reduce such pressures if they show that their policies are aligned with those of courts of other countries.

In a similar vein, a given state court may be reluctant to unilaterally rule that a given agreement required it to adopt a more expansive policy with respect to providing sanctuary for refugees not because it feared that its government would be punished by other governments or by international organizations, but because it feared if it would become a magnate for more refugees than it possessed the capacity to accommodate. If a substantial number of countries were to make a similar ruling simultaneously so that the refugee burden was shared among them, this problem too could be avoided.

Thus, domestic courts seeking to enhance their authorities must try to ensure a common interjudicial stance. For these reasons, interjudicial cooperation has become an increasingly popular strategy for national courts determined to protect their own authority and sustain domestic democratic processes in the face of runaway executives. Courts have been able to initiate and maintain cooperation through mutual exchange of information. Reliance on the same or similar legal sources-similar provisions in domestic constitutions or in international treaties such as the Convention against Torture, the 1951 Geneva Convention on the Status of Refugees-facilitates this communication between domestic courts and, to a considerable extent, signals their commitment for cooperation.

The development of such a common interjudical stance among national courts will not be easy of course. There are often marked differences in the positions of the national courts of the largest and most economically developed democracies, and the differences between these courts and those in marginally democratic states or nondemocracies are often likely to be unbridgeable. Still, the development of a common interjudicial stance is in the interests of national courts generally and some progress may be possible. It also may turn out that because the courts in nondemocratic states are not independent of their respective governments, they will have relatively little influence in any collective consultation process and may even be less likely to participate. If that were the case, the common interjudicial stance emerging from this collectivity of national courts might reflect a stronger emphasis on democratic values than the law produced by governments.

Of course, not all courts will be equally keen to safeguard the domestic political process. Courts in more powerful countries can be expected to show less sensitivity to the exposure of their government to external pressures in inter-governmental decision-making, because the courts assume their governments enjoy a greater ability to resist such influences. Given American dominance in setting global standards, we can anticipate less involvement by the U.S. federal courts in the President's conduct of diplomacy, and in fact, this is precisely what emerges from the defiant jurisprudence of the U.S. Supreme Court in this context. ${ }^{56}$

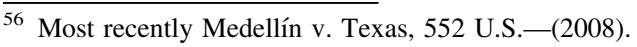




\section{Conclusion: towards global checks and balances?}

The traditional maps of checks and balances at the domestic level are continually being redrawn in a never-ending struggle to both govern and to contain government. In an era of global inter-dependency and rapid growth and increasing importance of intergovernmental coordination it has become increasingly apparent that the judicial branches of governments must forge coalitions across national boundaries to remain effective domestically. By seeking to coordinate their stances, the courts are not motivated by utopian globalism, but, like their executive branch counterparts are acting in pursuit of their domestic interests and concerns. Such coordinated reviews on the part of national courts seem increasingly likely to prove to be one of the most potentially effective avenues for promoting democratic accountability within intergovernmental institutions. The growing assertiveness of this type of inter-judicial cooperation should be welcomed by those concerned about the effectiveness of intergovernmental cooperation: similar to the contribution of courts in the domestic context, judicial review has the potential of improving the legitimacy of intergovernmental institutions. Paradoxically, in an era increasingly dominated by globalization and international institutions, domestic courts are becoming crucial players whose input indirectly improves the accountability and hence legitimacy of intergovernmental action, and thereby contribute to the evolution of more democratic forms of international cooperation.

\section{References}

Alvarez, J. E. (1996). Judging the Security Council. American Journal of International Law, 90, 1.

Alvarez, J. E. (2005). International organizations as law-makers. Oxford: Oxford University Press.

Aust, A. (2000). Modern treaty law and practice. Cambridge: Cambridge University Press.

Benvenisti, E. (1993). Judicial misgivings regarding the application of international norms: An analysis of attitudes of national courts. European Journal of International Law, 4, 159.

Benvenisti, E. (1999). Exit and voice in the age of globalization. Michigan Law Review, 98, 167.

Benvenisti, E. (2005). Factors shaping the evolution of administrative law in international institutions. Law and Contemporary Problems, 68, 319-340.

Benvenisti, E. (2007). "Coalitions of the willing" and the evolution of informal international law. In C. Calliess et al. (Ed.), Coalitions of the willing-advantage or threat? http://ssrn.com/abstract= 875590. Accessed 23 January 2009.

Benvenisti, E. (2008a). Reclaiming democracy: The strategic uses of foreign and international law by national courts. American Journal of International Law, 102(2), 241-274.

Benvenisti, E. (2008b). United we stand: National courts reviewing counterterrorism measures. In A. Bianchi \& A. Keller (Eds.), Counterterrorism: Democracy's challenge (pp. 251-276). Oxford, United Kingdom: Hart Publishing.

Benvenisti, E., \& Downs, G. W. (2007). The empire's new clothes: Political economy and the fragmentation of international law. Stanford law review, 60, 595.

Bernhardt, R. (1999). Evolutive interpretation, especially of the European Convention on Human Rights. German Yearbook of International Law, 42, 11-33.

Cohen, J., \& Sable, C. F. (2005). Global democracy? Journal of International Law and Politics, 37(4), $763-797$.

De Wet, E. (2004). The chapter VII powers of the United Nations Security Council. Oxford, United Kingdom: Hart Publishing. 
De Wet, E., \& Nollkaemper, A. (2002). Review of Security Council decisions by national courts. German Yearbook of International Law, 45, 189.

De Witte, B. (1999). Direct effect, supremacy and the nature of legal order. In P. Craig \& G. de Burca (Eds.), The evolution of EU law (pp. 177-213). New York, United States: Oxford University Press.

Dunoff, J. L. (1998). The misguided debate over NGO participation at the WTO. Journal of International Economic Law, 1(3), 433-456.

Edwards, M., Hulme, D., \& Wallace, T. (1999). NGOs in a global future: Marrying local delivery to worldwide leverage. Public Administration and Development, 19(2), 117-136. http://www. gdrc.org/ngo. Accessed 23 January 2009.

Franck, T. M. (1992). The "Powers of appreciation": Who is the ultimate guardian of UN legality? American Journal of International Law, 86, 519.

Freeman, J. (2000). The private role in public governance. New York University Law Review, 75, 543.

French, D. (2006). Treaty interpretation and the incorporation of extraneous legal rules. International and Comparative Law Quarterly, 55, 281-314.

Gowlland-Debbas, V. (1994). The relationship between the international court of justice and the Security Council in light of the Lockerbie case. American Journal of International Law, 88, 643.

Grant, R. W., \& Keohane, R. O. (2005). Accountability and abuse of power in world politics. American Political Science Review, 99(1), 29-43.

Hirschl, R. (2004). Towards juristocracy: The origins and consequences of the new constitutionalism. Boston, United States: Harvard University Press.

Kennedy, D. (2005). Challenging expert rule: The politics of global governance. Sydney Law Review, 25, 5.

Kingsbury, B., Krisch, N., \& Stewart, R. B. (2005). The emergence of global administrative law. Law and Contemporary Problems, 68, 15.

Klabbers, J. (2002). An introduction to international institutional law. Cambridge: Cambridge University Press.

Kokkot, J. (1998). Report on Germany. In A.-M. Slaughter, A. S., Sweet, \& J. H. H., Weiler (Eds.), The European court and national courts-doctrine and jurisprudence. Oxford, United Kingdom: Hart Publishing 77-132.

Lauterpacht, H. (1958). The development of international law by the international court. Cambridge: Cambridge University Press.

Maclachlan, C. (2005). The principles of systemic integration and article 31(3)(c) of the Vienna convention. International and Comparative Law Quarterly, 54, 279-320.

Mattli, W., \& Büthe, T. (2005). Global private governance: Lessons from a national model of setting standards in accounting. Law \& Contemporary problems, 68, 225-262.

McNollgast. (1995). Politics and the courts: A positive theory of judicial doctrine and the rule of law. South California Law Review, 68(6), 1631-1689.

McNollgast. (2006). Conditions for judicial independence. Journal of Contemporary Legal Issues 15. http://ssrn.com/abstract=895723. Accessed 23 January 2009.

McWhinney, E. (1992). The international court as emerging constitutional court and the co-ordinate UN institutions (especially the Security Council): Implications of the aerial incident at Lockerbie. Canadian Year Book of International Law, 30, 261.

Meron, T. (2005). Revival of customary humanitarian law. American Journal of International Law, 99, 817-834.

Murphy, S. D. (2003). Contemporary practice of the United States relating to international lawU.S.-Russia polar bear agreement. American Journal of International Law, 97(1), 192-193.

Reinisch, A. (2007). The international relations of national courts: A discourse on international law norms on jurisdictional and enforcement immunity. In A. Reinisch \& U. Kriebarum (Eds.), The law of international relations-Liber amicorum hanspeter neuhold (pp. 289-309).

Reisman, W. M. (1993). The constitutional crisis in the United Nations. American Journal of International Law, 87, 83.

Richter, D. (2006). Does international jurisprudence matter in Germany? The federal constitutional court's new doctrine of "factual precedent". German Yearbook of International Law, 49, 51-76.

Schultz, N. (2006). Was the war on Iraq illegal? The German federal administrative court's judgment to 21st June 2005. German Law Journal, 7:26-44. http://www.germanlawjournal.com/pdf/ Vo107No01/PDF_Vol_07_No_1_25-44_Developments_Schultz.pdf. Accessed 23 January 2009.

Slaughter, A.-M. (2004). A new world order. Princeton NJ: Princeton University Press. 
Stein, E. (2001). International integration and democracy: No love at first sight. American Journal of International Law, 95(3), 489-534.

Steinberg, R. H. (2004). Judicial lawmaking at the WTO: Discursive, constitutional, and political constraints. American Journal of International Law, 98(2), 247-275.

Stone, A. (2007). The politics of constitutional review in France and Europe. International Journal of Constitutional Law, 5(1), 69-92.

U.S. National Security Council. (2006). The national security strategy of the United States of America. http://www.whitehouse.gov/nsc/nss/2006/nss2006.pdf. Accessed 23 January 2009.

Watson, G. R. (1993). Constitutionalism, judicial review, and the world court. Harvard International Law Journal, 34, 1.

Weiler, J. H. H. (2004). The geology of international law-governance, democracy and legitimacy. ZaöRV (Heidelberg Journal of International Law), 64, 547-562. 